\title{
COMPARATIVE STUDY OF USING DRAMA AND SIMULATION TECHNIQUES TOWARD STUDENTS' SPEAKING ABILITY
}

\author{
Eva Faliyanti ${ }^{1}$, Nanda Habib Firdaus ${ }^{2}$ \\ ${ }^{1}$ Muhammadiyah University of Metro, Indonesia. \\ 1evafaliyanti1980@gmail.com \\ ${ }^{2}$ Muhammadiyah University of Metro, Indonesia. \\ ${ }^{2}$ nandahabib7@gmail.com
}

\begin{abstract}
Speaking is one of the productive skills in English. It acts as an important skill which becomes a depiction of students' result in studying English. Oftentimes, English ability is measured by their speaking because it serves a tool of communication which represents the major interaction with other people. But in fact, the condition of a learning process in a sphere of speaking has not supported students to master speaking ability yet. The application of techniques and methods are actually not interesting enough to attract them. Students tend to be passive when they are in learning about material related to speaking.The objectives of this research are; to find out students' speaking score by applying drama technique; to find out students' score by using simulation technique; to find out whether the drama is better than simulation technique in increasing students' speaking ability. The population of this research is 37 students in the fourth semester of English Department at the Muhammadiyah University of Metro. The researcher conducts systematic random sampling design and pre-test and post-test control group design as a research instrument. The result of hypothesis test on test phases both provides the different result which uses 5\% significant degree, where a count is higher than $t_{\text {-table }}$ on the analysis data of post-test with $\mathrm{t}_{\text {-count }}=2,36$ and $\mathrm{t}_{\text {-table }}=2,12$. It shows that the students who are taught by drama technique having a higher score. In conclusion that drama technique is more effective than simulation technique in term of students' speaking ability.
\end{abstract}

Keywords: speaking ability, drama and simulation technique.

\section{INTRODUCTION}

1.1 Background

Speaking is one of the productive skills in English. It acts as an important skill which becomes a depiction of students' result in studying English. Oftentimes, English ability is measured by their speaking because it serves a tool of communication which represents the major interaction with other people. Furthermore, speaking ability is an intermediary to deliver and construct any kinds of information containing meaning in English. It is not only pronouncing the words or sentences but also delivering the message.

But in fact, the condition of the learning process in a sphere of speaking has not supported students to master speaking ability yet. The application of techniques and methods are actually not interesting enough to attract them. Students tend to be passive when they are in learning about material related to speaking. Most of them will just rely on their friends who are more active in the class. This phenomenon will absolutely influence students' learning behavior in the future. Especially in speaking, it has to apply more effective and supportive for attracting students' interest and spirit. The most important thing is the way how to choose and to use the effective techniques so that the learning process and result will be increased. 
1.2 Problem Identification

Based on the background of study above, there are some problems raised as follows:

1.2.1 Is there any significant difference between drama and simulation techniques to increase students' speaking ability?

1.2.2 Is drama more effective than simulation to increase the students' speaking ability?

1.3 Objectives of Study

Based on the problem formulation above, the research objectives are as follows:

1.3.1 To find out the differences between drama and simulation techniques in increasing students' speaking ability.

1.3.2 To find out whether drama will be more effective than simulation techniques to increase the students' speaking ability?

\subsection{Previous Research overview}

There are some previous research overviews which are done by researchers in this research. Detail of explanation about those previous research will be discussed as follows: The first researcher is Wianto, Tukir (2013) under the title "The Comparison of Speaking Ability Using Pair Discussion of Cooperative Learning and Repetition Drill of Audio Lingual Method at Different Self-Confidence Students Eleventh Grade of SMA N 1 Rumbia Academic Year 2012/2013". An Undergraduate Thesis is published by English Education Study Program, Teacher Training and Education Faculty, Muhammadiyah University of Metro.

The second research is from RatchadapornJanudom (2009) under the title: "Drama and Questioning Techniques: Powerful Tools for the Enhancement of Students' Speaking Abilities and Positive Attitudes towards EFL Learning". Published by English as an International Program, Chulalongkorn University, Thailand.

The last research is from Ansori, Isa. (2011) under the title: "Improving the Speaking Ability of the Eleventh Grade Students of MA Madrasatul Qur'an Tebuireng Jombang through English Speaking Simulation. Graduate Program in English Language Education, State University of Malang.

\section{LITERATURE REVIEW}

This theoretical review in this research is divided into four parts, they are: the concept of speaking ability, the concept of teaching speaking, the concept of drama, the last part is about a concept of simulation. The explanation of sub topic is as follow:

\subsection{The Concept of Speaking Ability}

Speaking is one of productive skill which is able to observe directly. It represents the oral ability of students that usually shows the interaction which can be observed by the researcher. As Brown (2004:140) defined "Speaking as a productive skill that can be directly and empirically observed, those observations are invariably colored by the accuracy and effectiveness of a test-taker's listening skill, which necessarily compromises the reliability and validity of an oral production test". It means that speaking can be observed directly and empirically because it shows the interaction of students and the accuracy and effectiveness of a test-taker's listening skill is needed to compromise the reliability and validity of the oral test itself. Furthermore, speaking is considered as one of the most important skills in learning one language. Because of that reason, speaking is considered as 
one of the most important skill because it is providing the communication among human beings which occupy important position both individually and socially.

2.2 The Concept of Teaching Speaking

Teaching speaking is not merely asking the students to produce sound. According to Nunan (2003:40), "Speaking is the same as an oral interaction which are conventional ways of presenting information, expression our idea and thought have in our mind".

So, speaking is not only expressing our ideas but also presenting new information to other. Speaking as an interactive process of constructing meaning always involves in producing words and the meaning depends on the context. Speaking is a productive oral skill. In fact, speaking - especially in a language other than our own is quite a complex undertaking which involves using all the different levels of language. So, here we need to try several strategies for teaching speaking that can be used to help language learners gain practice in speaking in a target language (Nunan, 2003:64).

\subsection{The Concept of Drama}

With respect to the methodological principles, drama techniques are based on the Communicative Approach. The principal goal of such approach is not focused on the linguistic accuracy, but rather on making the students communicate in the target language fluently. As Ulas (2008:877) comments, "although drama has existed as a potential language teaching tool for hundreds of years it has only been in the last thirty years or so that its applicability as a language learning technique to improve oral skills has come to the forefront". Drama activities foster pupils' socialization, critical thinking, problem-solving and improve oral communication skills, by exploring different language styles and registers (Aldavero, 2008:45).

As a matter of fact, by expressing their emotions and personality language is more easily retained (Desialova, 2009:65). As Ulas (2008:860) claims, if students experience the topics personally, these will be assimilated and not forgotten. Dramatic activities are able to achieve this task successfully. Students also lose their inhibitions, because by playing a role, they are able to "escape from their everyday identity". By giving them a special role, students, especially the shyest ones, feel encouraged and tend to abandon their embarrassment and shyness (Phillips, 2003:7).

\subsection{The Concept of Simulation}

There are a lot of definitions of the term "simulation", among which Dougill and Jones' (1987:21) are the very first researchers in this field. According to Dougill, "Simulation can be defined as a structured set of circumstances that mirror real life and participants act as instructed". Meanwhile, Jones in his own research defines simulation as a reality of function in a simulated and structured environment. This definition shows three essential elements in simulations: a reality of function, simulated environment, and structure.

The two definitions agree in that simulation "mirror real life" and "reality of function in a simulated and structured environment", which means that simulation is not real life, it is only a type of simulating real life in a simulated environment.

Besides, the students are allowed to bring the properties during the simulation as Kayi (2006:67) quoted that in simulations, students can bring items or objects to make a realistic environment. For example, if a student is acting as a singer, she can bring a microphone to sing. Through simulation technique, there are so many advantages for students in learning process. Simulation can bring fun for students 
and the teacher. Furthermore, the students can bring props to create the real situation.

\section{METHODS}

\subsection{Research Design}

Moh. Nazir (2008:84) stated, "Research Design is all of the process that is needed in the planning process and implementation of research". So, the researcher has a good mind to make a planning for research which is going to be described in this research. This research is comparative study and quantitative research.

The research is executed in English Department of the Muhammadiyah University of Metro. The design used in this research is pretest-posttest control group design. It can be looked at the following table:

Table 1. Pretest - Posttest Control Group Design

\begin{tabular}{cccc}
\hline Group & Pre Test & Treatment & Post Test \\
\hline $\begin{array}{c}(\mathrm{M})(\mathrm{R}) \\
\text { Experiment }\end{array}$ & $\mathrm{T}_{1}$ & $\mathrm{X}_{1}$ & $\mathrm{~T}_{2}$ \\
\hline$(\mathrm{M})(\mathrm{R})$ & $\mathrm{T}_{1}$ & $\mathrm{X}_{2}$ & $\mathrm{~T}_{2}$ \\
Control & \multicolumn{2}{c}{} \\
\hline
\end{tabular}

Note :

R: Randomization of experimental and control group

M: Matching experiment and control group

$\mathrm{X}_{1}$ : Treatment of speaking by using drama technique

$\mathrm{X}_{2}$ : Treatment of speaking by using simulation technique

$\mathrm{T}_{1}$ : Pre test, it will be given before treatment

$\mathrm{T}_{2}$ : Post test, it will be given after treatment

Based on the table of research design above, this experimental research encompassed two classes which divided by randomization then categorized as the control and experimental classes. Both of control and experimental classes receive a sequence of steps; pre-test, treatment, and post-test in order to recognize the improvement of students' speaking ability by using drama and simulation techniques.

3.2 Research Population, Sample and Sampling Technique

\subsubsection{Population}

A research has to own the sequence people or thing to be a subject of research. As Arikunto (2002:108) says that population is people or other things discussed in the research. In other words, the population is the total number of the subjects of an investigation. In this research, the population is all of the fourth students of English department of the Muhammadiyah University of Metro. The population of this research consists of 37 undergraduate students of English department of the Muhammadiyah university of Metro.

\subsubsection{Sample and Sampling Technique}

The sample is a part of the population that is covered as the main subject of observation. As Arikunto (2002:108) states that sample is a part of the population that is observed. Furthermore, Sugiyono (2010:81) stated that sample is a part of whole and characteristic from the population itself. Base on the definition, the researcher determines the sample of the research which is taken from the 
population. In this research, the sample taken are 18 students of the fourth-semester students in English department of UM Metro which the total of students is 37 students which consist of 10 boys and 27 girls and The sample is taken by using a sampling technique called by systematic sampling technique.

\subsubsection{Instrument of Study}

In this research, the research instrument that will be used by the researcher is an oral test. The test is the most appropriate instrument for collecting a data. For more clear information the instrument of the research can be seen by the table below:

Table 2. The Instruments Specification Table of Students Speaking Ability

\begin{tabular}{|c|c|c|c|c|c|c|c|}
\hline \multirow[b]{2}{*}{ Materials } & \multirow[b]{2}{*}{ Indicator } & \multirow{2}{*}{$\begin{array}{c}\text { Cognitive } \\
\text { Domain }\end{array}$} & \multicolumn{5}{|c|}{ Item } \\
\hline & & & Pro & Flu & Int & Gra & Com \\
\hline $\begin{array}{l}\text { News } \\
\text { Reporting }\end{array}$ & $\begin{array}{l}\text { Students are able to } \\
\text { perform the daily } \\
\text { conversation in a formal } \\
\text { and informal situation } \\
\text { based on various topics } \\
\text { and activities in basic } \\
\text { communication } \\
\text { competence. }\end{array}$ & $\mathrm{C5}$ & & & & & \\
\hline
\end{tabular}

Source: Lecturer lesson plan of speaking major for the fourth semester of English department of UM Metro

Specification table of the instrument is aimed to limit the instrument of the research to be proper and in line with the plan of research. It is quite important to arrange those in research. By applying those specification table of research, the research is going to be able to know the limit of his instrument.

3.2.4 Validity and Reliability

A measurement can be said as valid when the content of the measurement is eligible to measure an object which should be measured and suitable with the fixed criteria. Validity means an accuracy of a measurement in measuring data (Basrowi, 2010:17). So the validity can measure how valid the data got from the object which is observed by the researcher.

To measure the validity of the instrument, the researcher uses content validity. It is a process of instrument validation which is done by the experts. The experts check and measure the content of instrument which is made by the researcher. The main focus of this process is the expert's review and check the way how researcher conducts a valid instrument. The measurement criterion is such as grammar, vocabulary, content, aim, and punctuation. In short, for maintaining the validity of the data, the researcher used content validity. Content validity occurs when the experiment provides adequate coverage of the subject being studied. It means the tests are developed based on the materials given at fourth semester of English department at Muhammadiyah University of Metro.

In this research, the researcher helped by another observer as the inter-rater to compare the data results from the sample. Because the data is resulting from two raters, so the researcher used Cohen Kappa reliability test with the formula is as follows (Mary, 2012:276): 


$$
K=\frac{\operatorname{Pr}(a)-\operatorname{Pr}(e)}{1-\operatorname{Pr}(e)}
$$

Where:

$K \quad$ : Cohen's Kappa Index Value

$\operatorname{Pr}(a) \quad$ : Relative Observed Agreement

$\operatorname{Pr}(e)$ : Hypothetical probability of chance agreement

With:

$\operatorname{Pr}(a)=\frac{a}{n}$

Where:

$\operatorname{Pr}(a) \quad$ : Relative Observed Agreement

$n \quad: \quad$ Number of Subjects

Where:

$$
\operatorname{Pr}(e)=\left(n_{i+} \times n_{+i}\right)+\left(n_{i i+} \times n_{+i i}\right)+\left(n_{i i i+} \times n_{+i i i}\right) \ldots . .
$$

$\operatorname{Pr}(e) \quad$ : Hypothetical probability of chance agreement

$n_{i+} \quad: \quad$ Total score of the first category of Inter-rater I

$n_{+i} \quad$ Total score of the first category of Inter-rater II

$n_{i i+} \quad$ Total score of the second category of Inter-rater I

$n_{+i i} \quad$ Total score of the second category of Inter-rater II

$n_{i i i+} \quad$ Total score of the third category of Inter-rater I

$n_{+i i i} \quad$ Total score of the third category of Inter-rater II

The result of reliability will be categorized by some criteria base on Altman (1991:44) with the level of reliability as follows:

Table 3. Kappa Score Criterion

\begin{tabular}{clcc}
\hline No. & & Categories & \\
\hline 1. & Poor agreement & $=$ & Less than 0.20 \\
\hline 2. & Fair agreement & $=$ & 0.20 to 0.40 \\
\hline 3. & Moderate agreement & $=$ & 0.40 to 0.60 \\
\hline 4. & Good agreement & $=$ & 0.60 to 0.80 \\
\hline 5. & Very good agreement & $=$ & 0.80 to 1.00 \\
\hline
\end{tabular}

\subsubsection{Data Collecting Technique}

In collecting data, the researcher uses the test of each variable of the research. In this research, the researcher gives two kinds of test to the students as a sample. The test consists of an oral test (for speaking ability). To collect the data, the researcher uses pre-test and post-test. The pretest is given before the treatment and post-test are going to be given after the treatment has done applying in both classes. As Sugiyono (2012:76) state that in this design the post test gives after the experiment group gets some treatment. So, the result of the post test from the control group and experiment group will be compared. The researcher decides to use the test as a research instrument. As Brown (2000:384) argues that "a test is a method of measuring a person's ability or knowledge in a given domain".

3.2.6Data Analysis Technique

Data analysis technique of this research use normality test, homogeneity test, and hypothesis test. 


\subsubsection{Normality Test}

One of the best assumptions of statistic computation was that the data must sufficient the qualification of a normal distribution. So, analyzing the normality of distribution of students' is crucial. The description below explains the way of testing normality:

\section{Hypothesis Formula:}

$\mathrm{H}_{0}$ : The sample is from a normal distribution.

$\mathrm{H}_{1}$ : The sample is from abnormal distribution.

\section{Statistics Formula:}

$$
x_{\text {count }}^{2}=\sum_{i-1}^{k} \frac{\left(O_{i}-E_{i}\right)^{2}}{E_{i}}
$$

\subsubsection{Homogeneity Test}

In this research, the researcher uses F-test to know whether the data of experimental and controlled are homogeny or not. The formula of F-test is described below:

$$
\mathrm{F}=
$$

Source: Sugiyono (2012:276)

\subsubsection{Hypothesis Test}

If $\sigma 1=\sigma 2=\sigma$, and $\sigma$ is unknown, the statistic is:

$$
t_{h i t}=\frac{\bar{x}_{1}-\bar{x}_{2}}{S_{g} \sqrt{\frac{1}{n_{1}}+\frac{1}{n_{2}}}}
$$

Where: $S_{g}^{2}=\frac{\left(n_{1}-1\right) S_{1}^{2}+\left(n_{2}-1\right) S_{2}^{2}}{n_{1}+n_{2}-2}$

(Adopted from Ahmad, 2011:45)

The testing criteria received $\mathrm{H}_{\mathrm{o}}$ if $-\mathrm{t}_{\mathrm{daf}}<\mathrm{t}_{\text {hat }}<\mathrm{t}_{\mathrm{daf}}$, Where

$$
t_{d a f}=t_{\left(1-\frac{1}{2} \alpha\right),\left(n_{1}+n_{2}-2\right)} \text {. }
$$

\section{FINDINGS AND DISCUSSION}

4.1 The Validity of Research Instrument

In following this research, the researcher used pre-test and post-test as instruments with validation of the content validity. The test was validated by two advisors to know the validity level before the researcher committed the test. The expert of this validation are speaking lecturer of the Muhammadiyah University of Metro, they are Aulia Hanifa Qamar M.Pd as the first validator (validator I) and Lilis Sholiha., M.Pd as the second validator (validator II). After the experts signed the instruments as an agreement that the instruments were categorized valid and legalized by the head of English Education Study Program as well.

4.2 The Reliability of Research Instrument 
To test the reliability of speaking test on this research, the researcher used Cohen Kappa. The result shows that the reliability score of speaking instrument is 0 , 94. It means that the reliability of is categorized as "excellent". For more information, the categorization can be seen from the table below (based on Murti, 1997):

Table. 4 Cohen Kappa Specification Table

\begin{tabular}{|c|c|}
\hline Kappa Score & Category \\
\hline Kappa $<0,4$ & Bad \\
\hline Kappa $0,4-0,6$ & Fair \\
\hline Kappa $0,61-0,75$ & Satisfying \\
\hline Kappa $>0,75$ & Excellent \\
\hline
\end{tabular}

\subsection{The Result of Post Test}

The researcher conducted the post-test to know the achievement of the students' vocabulary after giving the treatments. The post test was given on Wednesday, May $3^{\text {rd }}, 2016$ to the 18 students, where the 9 students were experimental 1 class and the 9 students were included as the experimental class 2 . The test consists of 10 items in oral test (interview) which were done by all of the students in both classes. The following is the table which will show more detail information about the result of the post-test which has done by the researcher.

Table 5. The Data Result of Post-Test Score of Experiment Class I

\begin{tabular}{cccccc}
\hline No. & CODE & Rater I & Rater II & Total & Average \\
\hline 1 & 2 & & & & \\
\hline 2 & 6 & 56 & 60 & 116 & 58 \\
\hline 3 & 10 & 65 & 68 & 133 & 67 \\
\hline 4 & 14 & 75 & 77 & 152 & 76 \\
\hline 5 & 18 & 76 & 76 & 152 & 76 \\
\hline 6 & 22 & 77 & 75 & 152 & 76 \\
\hline 7 & 26 & 84 & 86 & 170 & 85 \\
\hline 8 & 30 & 86 & 86 & 172 & 86 \\
\hline 9 & 34 & 88 & 84 & 172 & 86 \\
\hline & & & & & $\mathbf{7 3}$ \\
\hline
\end{tabular}

Source: the result of post-test in experiment class I

Table 6. The Data Result of Post-Test Score of Experiment Class II

\begin{tabular}{cccccc} 
No. & CODE & Rater I & Rater II & Total & Average \\
\hline 1 & 4 & 33 & 35 & 68 & 34 \\
\hline 2 & 8 & 43 & 45 & 88 & 44 \\
\hline 3 & 12 & 52 & 54 & 106 & 53 \\
\hline 4 & 16 & 56 & 56 & 112 & 56 \\
\hline 5 & 20 & 56 & 58 & 114 & 57 \\
\hline 6 & 24 & 63 & 63 & 126 & 63 \\
\hline 7 & 28 & 68 & 65 & 133 & 67 \\
\hline 8 & 32 & 69 & 71 & 140 & 70 \\
\hline 9 & 36 & 75 & 75 & 150 & 75 \\
\hline & & & & & $\mathbf{5 8}$
\end{tabular}

Source: the result of post-test in experiment class II 
Relating to the data above on the table 12 that the data of students' post-test can be described as follows:

a) The data of students' post-test shows that mean of experiment class I is 73 and experiment class II is 58 .

b) The mean of experiment class I is higher than experiment class II that $73>58$.

Below is the graphic of the different result between experiment class I and experiment class II:

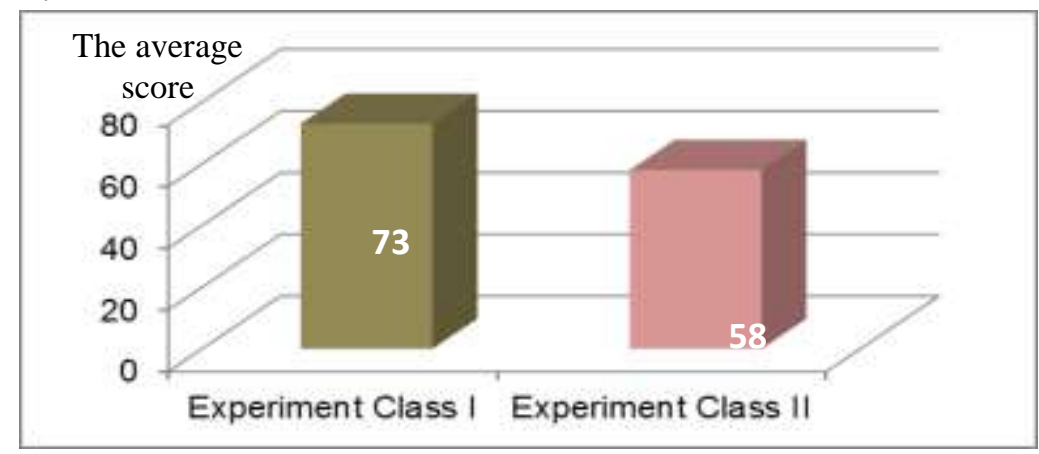

Source: the result of post-test in experiment class I and II

\subsection{The Result Normality Test}

Figure 1. The Graphic of Students' Post-Test Score

The result of Post-test calculation on the experimental class I and II show that $\mathrm{x}^{2}$ count are lower than $\mathrm{x}^{2}$ table whether for significant degree $0,05(5 \%)$ or $0,01(1 \%)$. Those proved that the post-test data in experiment class I and II is a normal distribution.

4.5 The result of Homogeneity test

The result of the post-test data calculation on both classes show that $F_{\text {count }}$ is

lower than $2^{F_{1}} 2^{\alpha\left(v_{1, v_{2}}\right)}$ even it is compared with significant degree $10 \%$ or $2 \%$ such as: $1,22 \leq 3,36$ (for significant degree 10\%), and 1,18 $\leq 2,90$ (for significant degree $2 \%$ ). Base on the test criteria above, it can be concluded that $\mathrm{H}_{0}$ is accepted. It proves that both samples come from a homogeneous population or have the same variance.

4.6 The Hypothesis Test of Post-Test

In following to calculation above, the data shows $t_{\text {count }} \geq t_{\text {table }}$ where $2,36 \geq 2,12$. It can be concluded that $\mathrm{H}_{0}$ is rejected and $\mathrm{H}_{1}$ is accepted. It means that the average learning result of experiment class $\mathrm{I}$ is higher than the average learning result of experiment class II.

\section{CONCLUSION}

After the treatment has done to be applied the result then compare to recognize the final information coming from those data. As Sugiyono (2012:76) state that in this design the post test gives after the experiment group gets some treatment. So, the result of the post test from the control group and experiment group will be compared. The result of hypothesis test on test phases both provide the different result which using significant degree $5 \%$, where $t_{\text {count }}$ is higher than $t_{\text {table }}$ on the analysis data of pret-test with numeral $t_{\text {count }}=2,51$ and $t_{\text {table }}=2,12$.

Meanwhile, on the analysis data of post-test also shows the same result that $t_{\text {count }}$ is higher than $t_{\text {table }}$ where $t_{\text {count }}=2,36$ and $t_{\text {table }}=2,12$. Thus, it means that the drama technique is better than simulation technique in teaching speaking of fourth 
semester students of English Department at Muhammadiyah university of Metro. The data is also supported by the average score of pre-test and post-test in experimental Class I and experimental class II. At the pre-test, experimental class I which the drama technique is applied show that the average score is 52 (fifty two). Whereas, the average score of experimental class II which applied simulation show that the average score is 51 (fifty one).

Furthermore, the data analysis shows the passing percentage of students in speaking class. The passing grade of speaking ability in post-test score is 60 (sixty). The number of students in an experimental class I (drama) who did not pass the grade is 2 (two) students of the total number of students which is 9 (nine) students or about $22,2 \%$ students who did not pass the test. Whereas, the number of students at experimental class I who passed the test is 7 (seven) students or about $77,8 \%$ of 9 students. In experimental class II or simulation class shows that the number of students who did not pass the test is 6 (six) students or $66,7 \%$ of 9 students.

Besides, the number of students who passed the test are 3 (three) students $33,3 \%$ from total students. Reflecting to the final score and its percentage, it can be stated that drama technique is better than simulation technique in speaking class of fourth-semester student of English department at Muhammadiyah University of Metro.

\section{REFERENCES}

Altman DG. (1991). Practical Statistics for Medical Research.London England: Chapman and Hall.44.

Arikunto, S. (2002). Prosedur Penelitian. Jakarta: Rineka Cipta. 108

B, Murti. (1997). Prinsip dan Metode Riset epidemiologi. Edisi ke 3. Yogyakarta: Gajah Mada University.

Basrowi (2008). Memahami Penelitian Kualitatif. Jakarta. Renika Cipta. 17

Brown, H. Douglas. 2004. Language Assessment: Principles and Classroom Practices. New York: Pearson Education.

Goddard MA, Dougill AJ, Benton TG: Scaling up from gardens: biodiversity conservation in urban environments. Trends in Ecology \& Evolution 2010, 25: 90-98.

Mary, L. M. (2012), Interrater Reliability: The Kappa Statistic. Biochemia Medica. U.S: Croatian Society for Medical Biochemistry and Laboratory Medicine. 276.

Nunan, D. 2003. Practical English Language Teaching. New York: McGrawHill / Cotemporary.

Philips, S. C., (2003) Drama with children. Oxford: Oxford University Press.30 Richards, Jack (1985) "Conversational competence through role play". RELC Journal 16:1

Sugiyono. 2013. Metode Penelitian Kuantitatif Kualitatif dan R \& D. Bandung: Alfabeta. 112. 276

Ulas, A. H. (2008). Effects of Creative, Educational Drama Activities on Developing Oral Skills in Primary School Children. American Journal of Science Applied. 876-877. 